Florida International University

FIU Digital Commons

FIU Electronic Theses and Dissertations

University Graduate School

4-11-2000

\title{
The function and failure of plantation government: interpreting spaces of power and discipline in representations of slave plantations
}

Karen Michelle Carson

Florida International University

DOI: $10.25148 /$ etd.FI14052590

Follow this and additional works at: https:// digitalcommons.fiu.edu/etd

Part of the English Language and Literature Commons, History Commons, and the Race, Ethnicity and Post-Colonial Studies Commons

\section{Recommended Citation}

Carson, Karen Michelle, "The function and failure of plantation government: interpreting spaces of power and discipline in representations of slave plantations" (2000). FIU Electronic Theses and Dissertations. 2060.

https://digitalcommons.fiu.edu/etd/2060 
FLORIDA INTERNATIONAL UNIVERSITY

Miami, Florida

THE FUNCTION AND FAILURE OF PLANTATION GOVERNMENT:

INTERPRETING SPACES OF POWER AND DISCIPLINE

IN REPRESENTATIONS OF SLAVE PLANTATIONS

A thesis submitted in partial fulfillment of the

requirements for the degree of

MASTER OF ARTS

in

ENGLISH

by

Karen Michelle Carson

2000 
To: Dean Arthur W. Herriott

College of Arts and Sciences

This thesis, written by Karen Michelle Carson, and entitled The Function and Failure of Plantation Government: Interpreting Spaces of Power and Discipline in Representations of Slave Plantations, having been approved in respect to style and intellectual content, is referred to you for judgment.

We have read this thesis and recommend that it be approved.

Lisa Ann Blansett

James Sutton

Linda Strong-Leek, Major Professor

Date of Defense: April 11, 2000

The thesis of Karen Michelle Carson is approved.

Dean Arthur W. Herriott College of Arts and Sciences

Dean Richard L. Campbell Division of Graduate Studies

Florida International University, 2000 


\section{ABSTRACT OF THE THESIS \\ THE FUNCTION AND FAILURE OF PLANTATION GOVERNMENT: \\ INTERPRETING SPACES OF POWER AND DISCIPLINE IN \\ REPRESENTATIONS OF SLAVE PLANTATIONS \\ by}

Karen Michelle Carson

Florida International University, 2000

Miami, Florida

Professor Linda Strong-Leek, Major Professor

This investigation focuses on representations of the physical construction and landscape of Southern slave plantations in order to explore the power relationships among inhabitants of those plantations and how those power relationships attempted to function and failed to establish a system of discipline and governance. While every plantation functioned violently in some form, many plantations appear to have attempted to instill a sense of place and permanence of status in slaves with more than just physical violence or obvious and overt forms of mental coercion and abuse. As a supplement to the strategic (and oftentimes random) physical violence inflicted on slaves in the attempts to control their behaviors, owners seem to have also attempted to discipline their slaves through strategic constructions of the plantation landscapes. While concluding that this strategy ultimately failed, this thesis examines attempts by owners to implement particular strategies in regulating and disciplining the behavior of slaves which can be compared with the strategies implemented in a panoptic system as described by Michel Foucault. 
TABLE OF CONTENTS

CHAPTER

PAGE

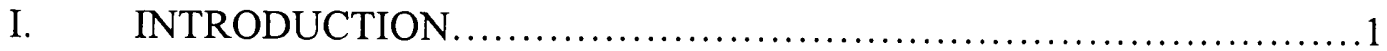

II. PANOPTIC DISCIPLINE AND DESIGNS...........................

III. THE FUNCTION ..............................................20

IV. THE FAILURE ..............................................40

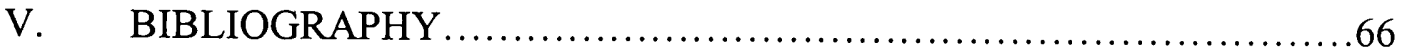


The Function and Failure of Plantation Government: Interpreting Spaces Of Power and Discipline in Representations of Slave Plantations

Introduction

This investigation focuses on representations of the physical construction and landscape of Southern slave plantations in order to explore the power relationships among inhabitants of those plantations. This thesis analyzes how the plantations' physical constructions signified one strategy used by owners in their attempt to discipline and govern slaves. While every plantation functioned violently, many owners appear to have attempted to instill a sense of place and permanence of status in slaves with more than just physical violence or obvious and overt forms of mental coercion and abuse. As a negative and thwarting position of inferiority and misery, the position slaves were forced to exist within represented an inhumane designation and relegation to the worst possible conditions of living; as a result of the inevitably violent conditions created by humans owning other humans in addition to the exclusion and denial of slaves' humanity within their delegated position, there could never have existed a slave plantation that did not utilize continual means of repression and violence in its attempt to enforce the social and class relationships desired by owners. As one strategy in creating this cognitively and physically bound place for slaves, and in the attempt to impress upon slaves the futility of their resistance to the role and life delegated to them by owners, owners used invasive and corporal punishment. As a supplement to the strategic (and oftentimes random) physical violence inflicted on slaves in the attempts to control their behaviors, however, owners seem to have also attempted to discipline their slaves through strategic constructions of the plantation landscapes. These landscapes represented owners' 
manipulation of space and their attempt to reconstruct and further manipulate slaves' identity in the owners' favor.

Representations of the plantations' physical landscapes seem to appear as one of the most interesting and perhaps most specifically detailed areas where owners most inconspicuously manipulated relationships of the inhabitants of the plantation in their own interest. More specifically, the arrangement of the buildings on the plantation and the architecture of those buildings closely resemble the arrangement of Jeremy Bentham's Panopticon as discussed in Michel Foucault's Discipline and Punish. With a central big house acting as the eye of the panoptic arrangement of the plantation, the kind of disciplinary mechanisms acting within the Panopticon could be seen to have been, in the owners' eyes, represented on the plantation. The panoptic arrangement of the plantation seems to have been used in the attempt to supplement physical violence with disciplinary mechanisms that would contribute to plantation management and aid in eliminating some of the retaliation and resistance from the slave population.

In many representations of slave plantations, such as those found in Frances Harper's Iola Leroy, Charles W. Chesnutt's The Marrow of Tradition, and in narratives by Booker T. Washington, Frederick Douglass, and Charles Ball, narrators include evidence of slave life that supports the idea that some plantations did in fact attempt to operate in ways that would have transcended at times the exclusive use of physical violence ${ }^{1}$.

Furthermore, in descriptions of plantation life, in recollections of the landscapes of the plantations, and in the few but marked accounts of interactions among slaves, a pattern

\footnotetext{
' In these representations, one must recognize the historical situation of narrators describing these spaces, and one must understand that violence, whether subtly psychological or blatantly physical, was present at all times.
} 
emerges in which one can discern distinct attempts by owners to implement particular strategies in regulating and disciplining the behavior of slaves which can be compared with the strategies implemented in a panoptic system as described by Foucault.

Foucault explains that "the exercise of discipline presupposes a mechanism that coerces by means of observation; an apparatus in which the techniques that make it possible to see induce effects of power, and in which, conversely, the means of coercion make those on whom they are applied clearly visible" (171). In plantation systems, one of the major keys to establishing a disciplinary regime involved creating this "means of observation" through the physical placement and construction of the buildings of the plantation itself. The disciplinary tactics of the owners in the plantation system always included and relied on more than the slaves' appropriation of and action within the field of the owners' gaze; panoptic tactics of discipline alone were ineffective and therefore incidental to other physically violent disciplinary techniques. Excessive violence as punishment for undesirable actions had more of an effect in evoking desired behaviors from slaves than did any appropriation or internalization of the owners' gaze; nonetheless, attempts at regulating, controlling, and "normalizing" slave behavior included forms of strategic punishment that parallel panoptic disciplinary mechanisms.

Foucault argues that punishment, as one element of disciplinary power, "normalizes" (183). In order for plantation punishment to work disciplinarily, it had to create a standard to which every slave felt drawn to adhere to. For owners, punishing slaves was meant to force them to act within the owners' limitations and definition of their role within the slave class; when slaves fell short of the slave "norm" created by owners, they were shown through either punishment of themselves or punishment of 
other slaves what the consequences would be. Foucault argues that punishment is not meant to repress but to establish normal and apparently appealing conditions to which one desires to work toward and to participate within. Obviously, repression was constant and inherent within slavery. Owners nevertheless seem to have been using some forms of punishment and offering what they considered to be "rewards" to slaves for appearing to comply with plantation rules that supplemented strictly physically violent forms of punishment and were parallel in ways to panoptic tactics of discipline and punishment. By punishing slaves for different "unacceptable" behaviors, owners appear to have been attempting to create a concept of a "normal slave"- the owners" "perfect slave." Punishment of this sort was a means of repression of particular behaviors but also a means of coercion and an example of opposition to "rewards" for behaving within limitations, such as a free night to go to a meeting, a "promotion" to a position in the big house, a position as a driver, or even a position as an overseer of other slaves. Obviously, the "rewards" as well as the punishments were carefully distributed and controlled if not directly by the owner then through particular intermediary authorities empowered by the owner; in different yet no less significant ways, "rewards" themselves simply produced different and, in many cases, even more stringent limitations on slaves' actions.

From the master's viewpoint, the slave who ostensibly had internalized the master's ideals as represented through his or her apparent compliance to the rules and regulations of the plantation could also, by virtue of his or her physical proximity to the house, possibly reinforce the "watch" over the other apparently less-compromising slaves on the plantation. For this reason and more, a slave who acted his or her part successfully according to the master's limitations and restrictions ultimately made his or her own life 
in addition to the lives of all other slaves even more difficult; the slave who appeared to be complicit was "rewarded" for his or her seeming passivity and became a fictitious standardized role model, the embodied slave norm, to which all other slaves were held and punished accordingly by.

In "gaining" a "position" on the plantation, however, the "rewarded" slave often lost more than just his or her physical distance from the big house and the owner himself. In eliminating physical space between himself and particularly "outstanding" slaves, the owner attempted to produce for other slaves the illusion of a "closer" aesthetic, material, and social existence to his own. Valuing material possessions and capitalistic gains as rewards for their own efforts, owners attempted to entice slaves with similar types of "compensation" for the slaves' participation within their confines. Owners imagined that offering the most aesthetically and materially pleasing existence possible for slaves as compensation for their cooperation and compliance with rules and within their designated role, and in comparing that existence and in assessing the benefits of that position in the house from the marginal positions of other slaves on the plantation, the other slaves would see and believe that the slaves in the big house were better clothed, ate better food, and were treated better physically. Owners wanted the house slaves to appear to have the best of everything available to any slave, whether or not that appearance was a true representation.

However well the owner's constructed illusion may have fooled visitors to the plantation, most slaves were much more adept at comprehending the owners' desires than the owners were aware of. Material benefits did not outweigh the actual physical and mental demands that accompanied physical proximity to the big house; slaves outside of 
the big house were constantly watched, but they were not constantly under the owner's roof and within his grasp. While the "rewards" and punishments for slaves may have been tactics for establishing owners' desired norm for slave behavior, slaves were intuitively adept at comprehending the paradoxical privileges of adhering to that norm. Their functioning within the norm was a response to their desire to stay alive rather than to win favor with and rewards from the owners.

Rewards and punishments functioned disciplinarily only in conjunction with other forms of discipline implemented throughout the plantation. Foucault discusses two "images" of discipline which are useful in analyzing the distinction between the kind of physically violent control that owners inflicted on their slaves and the kind of less physically violent, yet more psychologically detrimental, mental governance owners imposed. He explains that "at one extreme, [there was] the discipline-blockade, the enclosed institution, established on the edges of society, turned inwards toward negative functions: arresting evil, breaking communications, suspending time" (209). This extreme appears predominantly in the disciplinary function of plantation violence and control; discipline worked physically and with boundaries that were inflicted and enforced through fear. Guarded, bound, and "suspended" on a plantation without relationships of community beyond that which was specifically predicated, the slave was forced mentally and physically to behave as delineated by masters. In addition, though, the fact that plantation landscapes were constructed so strategically lends proof to the idea that less physically violent and more mentally coercive forms of panoptic discipline were perhaps being used in conjunction with physically violent control. 
Foucault adds that "at the other extreme [of the discipline-blockade], with panopticism, is the discipline-mechanism: a functional mechanism that must improve the exercise of power by making it lighter, more rapid, more effective, a design of subtle coercion for a society to come" (209). In order for a plantation to function most efficiently for owners, workers and slaves would have had to not only understand their place and their relationship within the dominator and dominated positions but act within their designated roles consistently. Everyone would have had to have had the feeling that he or she was always the subject of his own actions while at the same time acting within a system which established that subjection. In addition to having someone watch and punish or reward, the kind of plantation that masters ultimately seemed to have desired would have incorporated slaves as participants in their own fulfillment of their designated role as slaves, with the owners' desires and goals appropriated, incorporated, and functioning as slaves' own ideology.

While disciplinary strategies for attaining a functioning panoptic system seem to have been used within the plantation system, slaves were always already acting under extremely violent conditions that negated owners' aspirations for creating any willing position from which slaves would participate in plantation society; bodies owned are not bodies that can behave as participants.

Foucault argues that slavery was not a "discipline"; disciplines "were not based on a relation of appropriation of bodies; indeed, the elegance of the discipline lay in the fact that it could dispense with this costly and violent relation by obtaining effects of utility at least as great" (DP 137). I argue that plantation owners implemented many of the architectural and spatial disciplinary techniques of the panoptic system in order to 
enforce and complement other strategies of establishing their desired social order among the inhabitants of those lands. While slavery ultimately did not function as a true discipline for many different reasons, rethinking slave management as incorporating panoptic forms of discipline can inform instances of arbitrary violence inflicted on slaves and can highlight the significance of instances of slaves' seemingly futile resistance within the plantation system.

Slaveholders recognized and addressed the fact that slaves had to be constantly restrained and that they themselves had neither the resources nor the power to control every facet of slave life without violent control and example; the fact that slaveholders relied so heavily on violence in controlling slaves and the fact that not every slave was constantly being beaten or could not constantly be physically bound by literal chains suggests that those slaves who performed within the delegated limitations of their role with respect to slaveholders' desires must have been aware of their own existence and function within the system. The representations of the physical landscape of slave plantations and the ways that those layouts effected the slaves' cooperative as well as resistant behaviors indicate a disciplinary regime or at least a strategy, a program, of representational spatial governance that planters appeared to have been practicing. 


\section{Chapter II}

Governance and discipline indicate relationships in which both the subordinate and the superordinate maintain somewhat negotiable positions of power. Michel Foucault argues that power relationships cannot exist when "a man is in chains" ("Subject and Power" 221). According to Foucault, power includes freedom and is "exercised only over free subjects" (221): "By this we mean individual or collective subjects who are faced with a field of possibilities in which several ways of behaving, several reactions and diverse comportments may be realized" (221). In addition, Foucault argues that " 'Government' designated the way in which the conduct of individuals or of groups might be directed; the government of children, of souls, of communities, of families, of the sick ... To govern ... is to structure the possible field of action of others" (221). In claiming authority and power over any other entity, the option of resistance must be possible; physical bondage, in Foucauldian terms, indicates a physical prowess that ultimately indicates powerlessness. Foucauldian analysis suggests that once loosed from physical restraint, once the physical bondage inherent in slavery is eliminated, all control and all positions exist conterminously.

In interpreting spaces of contestation for slaves, however, to ignore even the most limited attempts at agency is to risk reifying slaves' subordinance; denying that slaves attempted to resist their designated position implicitly supports the idea that slaves did not have particularly individual desires and "wants" prior to and within the inscription of slavery. Although slaves were constantly threatened with their lives for behaving outside 
delineated and permissible venues of action, slaves often acted "inappropriately" with the full knowledge of the possible consequences for their actions. Slaves resisted, and slaves had at least minimal agency. While Foucault may deny that slavery allowed any choice or incorporated any power relationship, his analysis ignores spaces where slaves narrate their own individual desire and argue their own participation in transcending designated roles of domination and subordination.

In The Slave Community, John Blassingame explains that "practically all interpersonal relationships leave the subordinate with some independence, some power, some resources as long as he possesses something valued by the superordinate, whether it be labor or deference" (289). Owners needed slaves' labor to make the plantation work, and, unfortunately, many slaves were led to believe that their survival depended on owners' welfare. Pastoral, paternal coexistence and interdependence among slaves and owners did not exist in the realm of the real; slaves were ultimately at the mercy of owners at all times.

In particular instances however, while limited and few, slaves still retained agency and the ability to act on their own volition. While owners literally held the lives of slaves in their hands, slaves held the livelihood of owners in theirs; therefore, both parties had to maintain relationships of power in order to insure their own survival. The slaves, according to Blassingame's formula, would inevitably possess at least a minimal amount of power and agency as a result of their value to owners. This agency and power surfaced in primarily individual acts of transgression and resistance, and while the acts themselves affected little or no change in plantation practices in most cases, they are 
undeniably representations of slaves' individual willingness to display and engage in even the most minimal exertions of resistance and personhood.

Individual acts of resistance were inherent in the system of discipline that owners were attempting to implement. Owners denied slaves individual will but, at the same time, insisted on slaves' individual restraint and composure, on their awareness of their individual actions and repercussions for those actions, and on their identifying their individual selves as integral and vital in contributing to the functioning of the plantation. Depending on slaves as vital to the productivity of the plantation and incapable of maintaining a constant watch over each individual slave body, owners attempted to control their living "property" by encouraging slaves to control themselves, by calling on slaves to act individually for the benefit of owners. Slaves were called on to act in the best interest of their owners and the plantation as a whole, as opposed to acting individually on their own behalf and in their own best interest. Blassingame states that The institutionally defined role of the slave required him to identify with his master's interest ... This was the kind of slave the master wanted: a laborer who identified so closely with his master's interest that he would repair a broken fence rail without being ordered to do so. Systematic labor, implicit obedience, and unconditional submission (as child to parent or soldier to general) was expected of slaves. (242)

While this paternal relationship never existed, owners' desire for slaves' identification and interpellation into the illusory patriarchy of the plantation led them to construct and employ various strategies in attempting to foster this identification. 
Being in the minority, owners attempted to govern by proxy, by having slaves govern themselves independently while still denying slaves the independence of true individuality or action. By interpellating slaves into a disciplinary regime where slaves were led to believe that they were active participants (where slaves were given particular responsibilities and therefore a feeling of necessity and importance, where slaves were presented with titles that were intended to indicate and to create for slaves the appearance of desirable and distinguished positions of dignity and pride separating them from the average slave on the plantation, where those positions established a hierarchy among slaves themselves and appealed to their desire to have some control over others) owners appear to have been incorporating mentally coercive techniques which were supplementary to physically violent strategies of manipulation and control.

Blassingame argues that "the unique norms or subculture of the group, its size, the spatial arrangements, frequency of interaction, and the superordinate's ability to observe the subordinates all affect the degree of submission" (285-86). Each of these elements points to the arrangement of the physical landscape of the plantation as one of the most important components of a functioning plantation government. Who owned the plantation, the acreage of the plantation, how the buildings were distributed and how the residents were distributed among the particular buildings, who came into contact with whom and how frequently those contacts were made between the owners, overseers, and slaves, all depended on a strategic physical layout of the land. Blassingame emphasizes that the landscape represented the ways that the residents of the plantation "viewed" each other, and he stresses that "the extent of surveillance is the key to internalization" (286). 
Early surveillance by and early incorporation and appropriation of the ideals of the master helped to maintain the masters' desired power relationship and governance of the plantation. Owners, fully acknowledging the necessity of surveillance in the slaves' recognition of and inculcation into their owners' ideology, took great pains to arrange their entire landscapes with respect to the ways that those landscapes would influence the slaves' (in addition to all the other workers') attitudes and behaviors towards their roles in participating in the functioning of the plantation.

Owners seemed to have imagined that they could possibly mold slaves' own identities through establishing a feeling of perpetual surveillance enforced through the strategic construction of the landscape. Owners appear to have attempted to create through the landscape an omniscient presence that would enforce self-regulation within the slaves and establish their identification with the masters' desires that Blassingame describes. Foucault, in his discussion of Jeremy Bentham's Panopticon, describes institutions in which control is maintained from a limited space with minimal supervision. Obviously, with the ratio of slaves to planters on most plantations and with the expanse of land having to be maintained, planters would have looked for strategies such as this in governing their territories. Arguably, as a result of this, plantations often seem to have panoptically designed landscapes, and the goal in constructing this kind of landscape could be seen to parallel the desired effects of the Panopticon as represented by Foucault:

[The Panopticon] is a type of location of bodies in space, of distribution of individuals in relation to one another, of heirarchical organization, of disposition of centers and channels of power, of definition of the 
instruments and modes of intervention of power. . . Whenever one is dealing with a multiplicity of individuals on whom a task or a particular form of behavior must be imposed, the panoptic schema may be used. It is - necessary modifications apart—applicable 'to all establishments whatsoever, in which, within a space not too large to be covered or commanded by buildings, a number of persons are meant to be kept under inspection'. (DP 205)

The Panopticon is a technique used to discipline, often within a system of governing, and it requires a physical and social heirarchization of bodies functioning in a power relationship. The panoptic arrangement on plantations was constructed to allow for a field of surveillance to be maintained without a body to actually watch everything at every moment and without the slaves being bound physically when they were not being watched directly; the owners relied on the ability of the panoptic arrangement of the plantation's being able to create in the slave an internalization of a feeling of being watched and an incorporation of a sense of social place in direct relation to the slaves' physical location.

The similarity of the plantation layout to that of the Panopticon becomes apparent in Foucault's mapping of the basic structure of Bentham's model:

... at the periphery, an annular building; at the center, a tower; this tower is pierced with wide windows that open onto the inner side of the ring; the peripheric building is divided into cells, each of which extends the whole width of the building; they have two windows, one on the inside, corresponding to the windows of the tower; the other, on the outside, 
allows the light to cross the cell from one end to the other. All that is needed, then, is to place a supervisor in a central tower and to shut up in each cell a madman, a patient, a condemned man, a worker, or a schoolboy. (DP 200)

Foucault states that "the Panopticon is a machine for dissociating the see/being seen dyad: in the peripheric ring, one is totally seen, without ever seeing; in the central tower, one sees everything without ever being seen" (201-2). In the panoptic arrangement and structure of the big house and the buildings around the big house the panoptic system was intended to function under many of the same pretenses. Centered and central to the workings of the plantation, the big house and the planter within remained distanced and impenetrable to slaves. The planter remained hidden but perpetually surveying the slaves through the representative eye of the big house. The view from the big house did not necessarily include the slaves' quarters; however, the intimidation and control of the entire system of slavery itself was meant to be reinforced each time the slaves took in their view of the big house from their front doors. The idea that the planter could watch but not be seen and that the slaves could see but not identify exactly who watched them or when they were watched, seems to embody what Foucault reiterates about Bentham's argument that "power should be visible and unverifiable": "Visible: the inmate will constantly have before his eyes the tall outline of the central tower from which he is spied upon. Unverifiable: the inmate must never know whether he is being looked at at any one moment; but he must be sure that he may always be so" (201).

Granted, overseers watched slaves much more closely than planters themselves, and overseers were responsible for disciplining those slaves who managed to resist the 
"eye." Foucault recognizes the overseer's intermediary position as an intermediary position necessary to panopticism, and he describes in detail the "hierarchized network," the "observers" and "informers," required to respond to and carry out the orders of the highest power while at the same time responding to the requests and problems presented by the lowest class. The function of these "interstitial" elements of the panoptic system is to "link together" and "extend" "the effects of power to the most minute and distant elements": "It assures an infinitesimal distribution of the power relations" (197).

The location of the overseer's house - most often inbetween the big house and the slaves' quarters - further represented his location in the overall hierarchy of the plantation. Like the slaves' quarters, the overseer's house was also under the constant eye of the big house. In addition, even though the overseer's house was physically above the slaves' quarters, forcing them to look up to it supposedly in deference, the overseer's house failed to command even the most insignificant amount of reverence and respect that the big house did as a structure in and of itself. Slaves tended to defer to the overseer out of fear of being physically reprimanded. Ultimately, according to Blassingame, "the overseer was the weakest link in the chain of plantation management": "Whatever his character, it was impossible for the overseer to supervise every detail of the slave's life. . . Overwhelmed by a multitude of duties, the overseer could not be everywhere at once and consequently could not keep the slaves under constant surveillance" (276). The overseer's role on the plantation basically filled a "gap" within the panoptic system, but, undeniably, the "tower," the big house, was meant to remain in constant control of the landscape. 
Beyond the intermediary role of the overseer, the panoptic quality of the plantation was an attempt to create within slaves a sense of bondage without literal ropes and chains. Slaves, while fully aware of the fact that they would be reprimanded for their failure to do so, were supposed to remain in their quarters at night and return to the fields or respective duties during the day without having a warden lock them in or let them out. Foucault states that Bentham's Panopticon relied on the same type of control, a system of mental power and subjugation without physical fetters. Foucault asserts that "there is no need for arms, physical violence, material constraints. Just a gaze. An inspecting gaze, a gaze which each individual under its weight will end by interiorising to the point that he is his own overseer, each individual thus exercising this surveillance over, and against, himself" (Power/Knowledge 155). While interiorization of the system was the goal of the Panopticon and certainly of the panopticism utilized in the construction of the plantation landscape, slaves more often than not responded to physical bodies keeping watch over them and immediately violent situations being inflicted onto them rather than to any interiorized gaze that would command their deference or influence their behavior.

The fact that each individual slave was not directly surveyed every minute of the day and the fact that the owners felt the need to reinforce the idea in the slaves that they were lower in rank and social position than the owners themselves indicates that the owners acknowledged their unstable and fictitiously omniscient position in the big house, the eye of the plantation. George McCall and J.L. Simmons argue that "there are always some resources and choices open even to the most abject slave" (qtd. in Blassingame, 289). Owners' recognizing the need for surveillance in maintaining control implies that slaves as well as owners had some form of power; the owner would not feel the need to 
worry about his slaves' behavior if they were powerless, completely submissive and complicit in their domination.

Plantations always functioned violently; the plantation system required not only physical violence but mental manipulation and the coercion of slaves' identification of self. Plantation ideology relied on slaves' falling victim to the illusion of themselves as selves functioning, acting, and maintaining a particular necessary role within a governmental system that functioned for everyone, including themselves. Slave owners attempted to teach, to train, slaves to believe that their place was a desirable location for their bodies and their acts through the physical construction of the landscape. Owners located slaves on the owners' own terms, both physically and mentally, through their precise layouts of the land.

Saidiya Hartman argues that slaves in fact "operat[ed] in and against the demands of the system, negotiating the disciplinary harnessing of the body, and counterinvesting in the body as a site of possibility" (51). Hartman discusses how slaves "exploit[ed] the limits of the permissible, creat[ed] transient zones of freedom, and reelaborat[ed] innocent amusements [as] central features of everyday practice" (50), where "practice" presents a "way of thinking about the character of resistance, the precariousness of the assaults waged against domination, the fragmentary character of these efforts and the transient battles won, and the characteristics of politics without a proper locus" (51). While violence and physically repressive tactics dominated the strategies for containing and limiting slave identity and performance, slaveholders nevertheless had to account for the fact that slaves could work deceptively and coercively in order to achieve particular wants and needs ignored and denied through slaveholders' violent manipulation. 
Within the landscape of the plantations, every single behavior could not be observed and resistance at times was in fact made possible by the ways that owners had constructed their territories. Slaves were often much more familiar with the plantations' layouts than were the owners or the overseers. Furthermore, within the very buildings that were meant to reinforce the slaves' submission and domination, the slaves managed to find spaces for renegotiating their positions for their own benefit.

While the panoptic system may have been implemented in owners' attempts at establishing a functioning system of government on the plantation, the violent and destructive bases of slavery itself always already precluded and eliminated the positions from which slaves and owners could perform the necessary reciprocal relationships for governance and discipline. 


\section{Chapter III}

Owners created and then designated specific places for their workers to live and labor based on owners' particular ideas about how the social relationships within the plantation should be represented. The different views of the landscape from the overseer's house and the slaves' quarters were views that the planter ultimately gave to those workers who lived on his land; owners decided how each building should be built and where each building should be placed. By controlling the architecture and the location of each building in which the plantation workers lived and worked, owners attempted to create manageable and interpretable spaces where they could maintain a particular social infrastructure. Although plantations differed from region to region depending on the type of crop being produced and the number of slaves planters owned, up until the Civil War most plantations were designed based on a similar format. Neither arbitrary nor incidental, the interior and exterior spatial arrangement of the buildings on Southern plantations intended to distinctly represent the power structure, the hierarchy, inherent within the governing system of that "peculiar institution."

John Michael Vlach argues in Back of the Big House: The Architecture of Plantation Slavery that

to mark their dominance over both nature and other men, planters acquired acreage, set out the boundaries of their holdings, had their fields cleared, selected building sites, and supervised the construction of dwellings and 
other structures. The design of a plantation estate was an expression of the owner's tastes, values, and attitudes. (1)

Representative of the owners' attempt to order nature and society on their terms, plantation landscapes "were laid out with straight lines, right-angle corners, and axes of symmetry, their mathematical precision being considered as a proof of individual superiority" (5). Furthermore, most wealthy planters chose as their guiding blueprints English manorial estates (4-5): "No longer just a large farm run with supervised captive labor, from the middle of the eighteenth century onward the ideal plantation was a large, tastefully appointed country estate belonging to a prominent gentleman" (5).

Frederick Douglass in My Bondage and My Freedom describes the great house of the first plantation on which he lived:

The great house itself was a large, white, wooden building, with wings on three sides of it. In front, a large portico, extending the entire length of the building, and supported by a long range of columns, gave to the whole establishment an air of solemn grandeur. It was a treat to my young and gradually opening mind, to behold this elaborate exhibition of wealth, power and vanity. (47)

Douglass's "young and gradually opening mind" took these images in and initially interpreted them very closely to the way that owners desired. The "solemn grandeur" of the house acted as candy, "a treat," that enticed and seduced the young Douglass. As a child unfamiliar with the conditions that he faced in his future role among the residents of the big house, he felt privileged to be able to partake of this magnificent display and to be a part of its landscape. Douglass's description of this house indicates his initiation into 
his role as a working slave within the system, and his recollection of his first reaction to the physical layout of the main representation of his owner's power and wealth indicates at least a minimal amount of success in his owner's techniques of fostering admiration and reverence for himself and his system.

The "vanity" that Douglass notes, however, glaringly indicates Douglass's recognition of the owner's ultimate desire to distinguish himself from all other levels of life surrounding the house and his land; his egotism surfaced in every facet of the approach and entrance into his "gentlemanly country estate." In order to approach the big house of a large plantation, a visitor might have to go through a number of "gates, drives, forecourts, steps, terraces, porches, passageways, doors" (Vlach 5); every extra threshold further exemplified an owner's intent to remain distant and distinct from the "outside world" in his power and social ranking. Douglass describes the entrance to the big house of the plantation where he lived by detailing many of these thresholds:

The carriage entrance to the house was a large gate, more than a quarter of a mile distant from it; the intermediate space was beautiful lawn, very neatly trimmed, and watched with the greatest care. . . The road, or lane, from the gate to the great house, was richly paved with white pebbles from the beach, and, in its course, formed a complete circle around the beautiful lawn. (47)

Visitors approaching the house were presented with a residence similar to that of "English nobility" and demonstrating an "Eden-like beauty" (47). Douglass adds that in its isolation, seclusion, and self-reliant independence, Col. Lloyd's plantation resembles what the baronial domains were, during the middle 
ages in Europe. Grim, cold, and unapproachable by all genial influences from communities without, there it stands; full three hundred years behind the age, in all that relates to humanity and morals. (46)

By associating themselves with an established English history through architecture in addition to subtly modifying that architecture to fit a certain landscape, planters attempted to secure an authoritative position for themselves not only among those slaves that they owned and the overseers that worked for them but also among the surrounding community.

In creating a dated existence, in connecting the house to an English precedent and patriarchal system of governance and domination, the slave owners claimed a stake in "original" occupation of the land; they presented themselves through their houses as sophisticated and dignified settlers with a tried and true system of "proper" ownership and governance. Slaves, in this presentation, ultimately occupied an uncivilized and yet necessary place in the functioning of a historically, Eurocentrically valued and yet mythical utopian manorial estate. In fashioning their estates upon the designs of the manorial estates of England, owners intended for the big house to define generations of domination and ownership and to demand respect and loyalty for those who lived thererespect and loyalty earned through years of what was meant to appear as an "obviously" superior existence.

Although an "ideal" plantation may have included a grandiose fantasy house overlooking a picture-perfect landscape, plantations fitting the English manorial estate description were actually quite rare in the South. Eugene Genovese states that "the overwhelming majority of the big planters, as well as the moderate to small planters, 
lived in simple two-story houses, tolerably spacious and comfortable but hardly the mansions of Gone With the Wind and the plantation legend" (533). Often small planters tried to emulate the wealthiest planters' homes and status by adding on a "Greek Revival porch, for example, complete with columns and entablature ... grafted awkwardly onto a humble log cabin as a statement of presumed sophistication" (8-9). For the most part, though, planters' homes were distinguished simply by their being bigger than any of the other buildings on the plantation and by virtue of their being centrally located with respect to the layout of the plantation itself.

In addition to the fact that the most elaborate displays of wealth were actually rare, Charles Ball argues that the effort to entice and to interpellate African slaves by aesthetically impressing them was a failure. He states that the African slaves "generally place[d] little, or even no value, upon the fine houses, and superb furniture of their masters" (355). Their values were established long before their introduction to American ideals of beauty and desire. In contrast, Ball asserts that "the case is different with the American negro, who knows nothing of Africa, her religion, her customs, and who has borrowed all his ideas of present and future happiness, from the opinions and intercourse of white people, and of Christians" (355). He states that while the most coveted belonging of the white man for a male slave was the owner's mistress, the "secondary objects of his desires" are "the possession of a spacious house, splendid furniture, and fine horses of his master" (356). Owners banked on being able to impress slaves and any other visitor or resident of their plantation with the overwhelming aesthetic beauty and intimidating largesse of their big houses. The big house, nestled among its surrounding buildings and an intimidating panoramic landscape, was intended to represent a complete 
history and a continuing future of an organic, symbiotic and productive relationship among all of the inhabitants.

The organicism of the plantation relied on each building performing a role within its proper place on the plantation. As previously stated, large plantations generally revolved around a big house situated somewhat centrally within the plantation and preferably on some sort of hill or higher ground than the rest of the buildings. The big house's "yard" contained several outbuildings-most often a kitchen, dairy, smokehouse, and well (Vlach 34). Douglass describes an example of this area in detail in his recounting the big house which he worked in:

The great house was surrounded by numerous and variously shaped outbuildings. There were kitchens, wash-houses, dairies, summer-house, green-houses, hen-houses, turkey-houses, pigeon-houses, and arbors, of many sizes and devices, all neatly painted, and altogther interspersed with grand old trees, ornamental and primitive, which afforded delightful shade in summer, and imparted to the scene a high degree of stately beauty.

Douglass's description, years after his first viewing this space, contains extreme detail and conveys a sense of contentment and comfort elicited from the buildings and the landscape. Douglass reflects through the language that he uses to describe this area his inability to resist feeling an affinity and admiration for this physical representation of the plantation system; the variety and "neatness" of the painted buildings, the "delightful" and "ornamental" yet "primitive" "grand" trees evoke an image of something naturally complex made simple and comprehensible. Douglass concludes his long and detailed 
description of the landscape with, "These all belonged to me, as well as to Col. Edward Lloyd, and for a time I greatly enjoyed them" (48).

Although he writes his narrative from a distance, and although his recalling this landscape is a recollection from his childhood, Douglass's language reflects that, even as a child (especially as an influential child), he comprehended his designated place within this "picture." In his acknowledging the "scene of stately beauty," he also acknowledged an initial and misguided desire to be a part of that beauty and to contribute to the wellbeing and maintenance of that facade. Douglass's scene reflects exactly the type of control that the planter wanted to enforce without ever lifting a hand. While the grandiose picture presented by these constructed landscapes produced a certain amount of awe, the surface visage of the plantation in such a representation trivialized and distorted the complex social and political underpinnings that kept the plantation "machine" running; paradoxically, the aestheticization of that stately scene functioned as a tool in maintaining an intricate balance of power among the plantation's members.

In distinguishing the smaller pieces of the panoramic view of the plantation, the individual structures and the arrangement of those structures contributes to an understanding of the complexity of the relationships among the different inhabitants of the land. The strategic placement and construction of each building in its relationship to the big house indicates a disciplinary gaze that was intended to structure the literal and figural distances in status and power among the different inhabitants. In venturing from the elaborate and overwhelming propensity of the big house and its yard to those outlying buildings, one would usually find the overseer's house somewhere near the side of the big house. Farther away but always within sight of the overseer's house lay the slaves' 
quarters. Ideally, the planter could look out and down from his house and easily "keep an eye on" the overseer's house without having to see the slaves' quarters. The overseer, from a house closer to the size of the slaves' quarters than the planters, could simultaneously look down and out into the slaves' quarters to make sure that all was functioning according to plan. If drivers were implemented, then usually the driver's quarters (which were no different in construction from the slaves' quarters) would be the first in the row of slaves' quarters. From here the driver could keep an eye over the other slaves while remaining closest to the eye of the overseer and yet still be physically "above" the other slaves. The slaves, as the lowest ranking class and social group, had nowhere to look but up, as was the intention of the planter. Forced to exist physically and socially below the overseer, the planter, and the driver, on lower lying land and in smaller quarters, the slaves were constantly reminded of their place in the plantation. While the physical placement of individual buildings helped to determine who watched whom, the construction of the buildings themselves also contributed to the power structure being created. The most important buildings architecturally besides the big house were the slaves' quarters. Each "family" of slaves had their own building which was usually square or rectangular and lined up with numerous other buildings just like it. Rather than house the slaves all together, which might thereby facilitate rebellion through collective action, the slaves were divided into domestic groups and housed in small "cubicles." As a family, which could also be considered to be yet another construction of a disciplinary mechanism used to control behavior, slaves were considered less likely to instigate revolution; the fear of risking the lives of loved ones overcame the impetus to rebel. Genovese notes that "the masters understood the strength 
of the marital and family ties among their slaves well enough to see in them a powerful means of social control. ... masters and overseers normally listed their slaves by households and shaped disciplinary procedures to take full account of family relationships" (452). Allowing slave families to live together in the same cabin certainly was not without its benefit to the planter. Constructing the slaves' living spaces as cells and then grouping the slaves into "families" within these cells contributed to yet another convenient way to further maintain a structured system of identification and manipulation of slaves by the planter.

The slaves as chattel, as themselves personal property of the planter, basically were stored away in "boxes" each night until they were needed for the next day's work. Vlach argues that "slave quarters ... [were], without exception, bare geometric expressions-square or rềctangular boxes with roofs":

Few of them had porches or shed additions that might indicate attempts by former slave occupants either to exercise a degree of choice in their houses' design or to personatize the buildings. The walls, often left unpainted, were pierced only by a door and a few square holes for windows, if there were any windows. Dark both inside and out, these buildings would only on rare occasions be taken for homes. (Big House 162)

Each cabin did contain a fireplace which sometimes was made of brick but more commonly was made of "lath or split sticks, laid up like log work and plastered with mud" (qtd. in Vlach 156). Slave cabins ranged in size from about 10 by 10 feet to the suggested and more humane 16 by 18 feet. Kenneth Stampp states that despite the fact 
that "Southern agricultural periodicals bristled with warnings to masters about the importance of furnishing good houses for their laborers" (293), "the common run of slave cabins were cramped, crudely built, scantily furnished, unpainted, and dirty" (294). The slaves' quarters were built with the intention of serving as "places to sleep and as shelters during inclement weather" (292). Vlach states that "quarters were meant to function chiefly as shelters for people who, by definition, were not allowed to own homes" (163). Vlach adds that "it is important to understand that slave quarters were only incidentally meant as residences; they were, foremost, the planters' instruments of social control" (165): "When viewed from the outside, slave quarters can be seen as instruments of control, as material devices used by planters to demean and brutalize their slaves" (169). The slave quarters inevitably represented the only domestic space in which the slave family could gather as such. That space, however, was unquestionably imbued with the owners' economic ideals and desires which, regardless of its imaginary function as a home, was intended to prevent slaves from imagining themselves as performing any other role than that of the one to which they were delegated. Several critics argue that despite the intention of the planters to simply compartmentalize slave families for the sole purpose of keeping them in more controllable economic units, the slaves still managed to create a sense of "home" out of the spaces that they lived in. Genovese contests that "the slaves created impressive norms of family life, including as much of a nuclear family norm as conditions permitted, and that they entered the postwar social system with a remarkably stable base" (451-2). Furthermore, Vlach argues that "beyond their master's immediate scrutiny, at the margins of the plantation and in the thickets beyond its 
boundary lines, slaves created their own landscape" (13): “. . . the degree of control achieved by the planters was nowhere near as absolute as they imagined" (169).

Despite what these critics may say, and despite the efforts of slaves to try and make the most out of truly horrible living conditions, the majority of slaves found it nearly impossible to maintain "normal" familial conditions within the space of the slave cabin'. Numerous slave narratives describe the intolerable conditions of many of their living quarters on plantations in the South while specifically recognizing that slavery as an institution prevented any type of stability within the domestic sphere of the slaves.

Frederick Douglass emphasizes the fact that neither of his parents were a part of his childhood - neither lived within any reasonable distance for any regular visitation or any significant relationship to exist between them. Douglass writes that the practice of separating children from their mothers, and hiring the latter out at distances too great to admit of their meeting, except at long intervals, is a marked feature of the cruelty and barbarity of the slave system. But it is in harmony with the grand aim of slavery, which, always and everywhere, is to reduce man to a level with the brute. It is a successful method of obliterating from the mind and heart of the slave, all just ideas of the sacredness of the family, as an institution. (29)

\footnotetext{
' While the idea of "normal" familial conditions was a Western idea and obviously not the "norm" for African families, most of the slaves writing novels and narratives were born in America and indoctrinated into not only the slave system itself but also many other American constructions that the slave system entailed.
} 
For slaves, any family values promoted by owners existed for the sole purpose of reproducing their investment or disciplining the slaves by constructing an atmosphere of relations that would pacify any aggressive attempts at overthrowing the system.

Douglass contributes to the idea that slaves were inducted into a system where the space that defined them was intended to deny them significant bonds among other members of their family. Douglass is taken from his grandmother's cabin at age seven and forced to live twelve miles away at the big house with "old master." When he arrives at the big house, he first realizes he has brothers and sisters whom he has never met or heard about before:

... slavery had made us strangers. I heard the words brother and sisters, and knew they must mean something; but slavery had robbed these terms of their true meaning. ... we had never nestled and played together. My poor mother, like many other slavewomen, had many children, but NO FAMILY! The domestic hearth, with its holy lessons and precious endearments, is abolished in the case of a slave-mother and her children.

Douglass argues that, in addition, slavery "does away with fathers, as it does away with families. Slavery has no use for either fathers or families, and its laws do not recognize their existence in the social arrangements of the plantation. When they do exist, they are not the outgrowths of slaver, but are antagonistic to that system" (38). Douglass's grandmother's cabin, however, is continually referred to as his first "home," and, as a child, he mourned his separation from "the old cabin, with its rail floor and rail bedsteads up stairs, and its clay floor down stairs, and its dirt chimney, and windowless sides.... 
[It] was MY HOME - the only home I ever häd; and I loved it, and all connected with it" (34).

Douglass's grandmother's cabin represents a space that arguably fostered an affinity for the kinds of relationships that could have instigated communal bonds. In Douglass's detailing the cabin where he spent his childhood, one of the most striking aspects of his description is his aestheticization of the cabin and its yard; in much the same style that he describes his first encounter with the big house, he describes how he viewed the cabin as a child:

It was a log hut, or cabin, built of clay, wood, and straw. At a distance it resembled - though it was much smaller, less commodious and less substantial-the cabins erected in the western states by the first settlers. To my child's eye, however, it was a noble structure, admirably adapted to promote the comforts and conveniences of its inmates. A few rough, Virginia fence-rails, flung loosely over the rafters above, answered the triple purpose of floors, ceilings, and bedsteads. (29)

Particular words in this passage signify Douglass's ambivalence about the cabin. Within the passage the cabin is referred to as "noble," "admirable," "comfortable." He compares the cabin to the cabins of settlers who were setting out on their own and establishing themselves in new lands, which seems to point to the slave cabin as a place where the slave could act in his own "frontier" of sorts. Furthermore, rather than call the cabin cramped and poorly built, Douglass describes it as "less commodious" and "less substantial." In contrast, though, he refers to the slaves living in the cabins, himself included, as "inmates." He knows in hindsight that that cabin is part of the slavery 
system, that the cabin is meant to reinforce the slave's identity with his delegated social place and materially inferior existence. Douglass writes that he first learned of his condition as a slave when he was a child living in this cabin: "I was A SLAVE-born a slave-and though the fact was incomprehensible to me, it conveyed to my mind a sense of my entire dependence on the will of somebody I had never seen; and, from some cause or other, I had been mad to fear this somebody above all else on earth" (34). The cabin contributed to the appropriation of the master's desired reverence for the system from the slave. Significantly, the similarity between Douglass's descriptions of the big house and of his own cabin highlights the possible initial influence of architecture in structuring the way that many slaves defined their sense of belonging and place.

The slave cabin provided (in the worst sense) a representation of one space where owners failed at creating a functioning disciplinary mechanism; family ties and ies to the cabin as a home were not in themselves particularly rewarding or "normalizing" in establishing and maintaining owners' ideal "slave behavior." When owners separated family members and eliminated stability for the slave even within the domestic sphere, they also negated their own attempts to create a controlling and controllable "family norm" within the slave society. Rather than constructing familial ties which might deter slaves from revolting and encourage slaves to behave in certain ways in order to be allowed to stay together, owners ended up inducing feelings of betrayal and anger from slaves who were constantly snatched out of any familial relationships and shifted from plantation to plantation. Douglass, as example, was taken from his "home" at seven years old and thrust into the work force of the big house. 
Douglas's summation of the results of slavery on the domestic sphere reinforces the idea that even though planters may have promoted the family unit within the slave cabins, their ultimate interest was simply in the economic success of the plantation as a whole and not the success of slaves' bonding with family members:

There is not, beneath the sky, an enemy to filial affection so destructive as slavery. It had made my brothers and sisters strangers to me; it converted the mother that bore me, into a myth; it shrouded my father in mystery, and left me without an intelligible beginning in the world. (43)

While Douglass's portrayal of the structure of the cabin that he lived in for the first seven years of his life was somewhat positive because of the sense of security he received there from his grandmother, Booker T. Washington's recollections of his childhood, even in the company of his mother, are far less enthusiastic. Unlike Douglass's mother who was a field hand, Washington's mother was a house slave, the plantation cook, and his family lived in the plantation kitchen-one of the outbuildings from the big house. Washington describes the atmosphere of this "home" as "miserable, desolate, and discouraging" (29). The kitchen, like the slave cabins, was a log cabin “about fourteen by sixteen feet square” (29). Similar to Douglass's cabin, Washington's had "only openings" for windows, with no glass or shutters, and the one door was hung on "uncertain hinges" with "large cracks in it" (30). The floor of the cabin was simply the "naked earth" (30), and Washington states that he slept on this floor "on a bundle of filthy rags" until he was released from slavery (31).

The relationships among the different members of Washington's family seem to be just as distant and strained as those described by Douglass. No rituals brought the 
family together for "special times." Washington recalls that even the most regulated instance of sitting together for a meal never occurred in the kitchen where his family lived: "I cannot remember a single instance during my childhood or early boyhood when our entire family sat down to the table together, and God's blessing was asked, and the family ate a meal in a civilized manner" (33). Even though Washington lived in the same building as his mother, she "had little time to give attention to the training of her children during the day" (31). Ultimately, Washington's relationship with his mother was almost as indistinct as Douglass's: "She was simply a victim of the system of slavery" (31). As the plantation cook living in such close proximity to the big house and therefore existing even closer to the eye of the planter than any other slaves, the time and energy expended in the continual effort to please the big house left little time for her to cater to her children's emotional needs.

Significantly, Douglass also lived in the plantation kitchen when he was brought as a child to the big house to begin acting officially as a slave. Although Douglass does not go into much detail about the construction of the kitchen itself, he does mention that he slept "on the floor of a little, rough closet, which opened into the kitchen" (58). In addition, Douglass describes the "kitchen family," consisting of "Aunt Katy, Aunt Esther, and ten or a dozen children, most of them older than myself" (53). He notes that the "house family" and the "kitchen family" (as well as the overseer's family) never ventured into each other's territory: "the idea of rank and station was rigidly maintained on Col. Lloyd's plantation" (53). This would indicate that the buildings themselves were meant to construct a particular behavior, a maintenance of place and station, simply through their location and their practical function. Proximity to the big house affected a more 
direct and immediately threatening relationship with the owner. The "idea of rank and station," knowing that walls were facades of privacy in a system where owners' influence penetrated every corner, functioned in enforcing and maintaining desired behaviors.

Second only to the big house in importance, the kitchen was ultimately a slave space that owners rarely entered. The cook maintained control over the kitchen, and as Douglass noted, it was just as taboo for the planter's family to move freely through the kitchen as it was for the kitchen family to wander through the big house. Vlach explains that as a territory almost exclusively run by slaves, the kitchen's separation from the big house marked a significant distancing between "those who served and those who were served" (43):

Until the last decades of the seventeenth century, slaves and their masters (at least in the Chesapeake region) lived and worked in close proximity, often in the same rooms, and sometimes shared a common identity as members of a plantation 'family.' But this day-to-day intimacy was replaced by a stricter regimen of racial segregation that was expressed by greater physical separation. The detached kitchen was an important emblem of hardening social boundaries and the evolving society created by slaveholders that increasingly demanded clearer definitions of status, position, and authority. (43)

The kitchen, similar to the slave cabins, represented a distinct space where slaves were forced to try to create some sort of domestic sphere for themselves under an ever-present surveillance. Without overstepping their boundaries, cooks had to take on a certain amount of independence in their attempt to impress the master at every meal; however, 
their place in the plantation was even more rigidly fixed than that of the field slaves because of the proximity of the building itself with relation to the big house and because of the cook's corporeal proximity. Furthermore, because the kitchen had to function as a work place in addition to a "resting place," any opportunity for a cook to create a domestic or homely space was automatically thwarted. Gilian Brown highlights the conflicting space set up by the plantation kitchen for the slave. She argues that "slavery disregards this opposition between the family at home and the exterior workplace. The distinction between work and family is eradicated in the slave, for whom there is no separation between economic and private status" (15). While providing what may have seemed like a more personal and individual space where owners would not physically move about, the kitchen also represented one of the most obvious examples of the utility of buildings in maintaining discipline on the plantation.

Douglass explains that in the kitchen where he stayed, Aunt Katy was given full reign of the kitchen, and because of her expertise as a cook, "she was the only mother who was permitted to retain her children around her" (51). In rewarding Aunt Katy for her "job well done," Col. Lloyd allows her what is intended to be seen and experienced as the privilege of motherhood beyond the biological experience. This "reward" functions disciplinarily in that it represents what owners would believe slaves would desire, a "normal" family; by following the example set by the kitchen slave in fulfilling the owners' established slave norm, other slaves might be given the opportunity to participate in what appears from the outside to be a more stable familial environment with their own building and their own children. The construction of the kitchen family functioned in much the same way as the construction of the field slaves' family in that it was a useful 
method of controlling slave behavior. The kitchen family, while appearing to offer slaves a chance to attempt to create positive bonds and relationships with each other, ultimately functioned within the strictest boundaries of the gaze of the owner, though, and with even less opportunity for privacy or for space that could be manipulated in any way outside of the owner's intended function.

Through a deliberate combination of the physical placement and the architectural construction of the buildings on the plantation such as the big house, the kitchen, and the slaves' quarters, owners believed that they could enforce discipline and internalization of their own construction of slaves' identity; owners attempted to mold and govern slaves' selves with their preferred landscapes. The kind of discipline desired through the construction of the plantation landscape functioned at least minimally in almost all cases where slaves initially came into contact with the territories and later recollected their experiences upon encountering and dwelling within and working among those spaces. Planters appear to have been attempting to set up plantations as physical representations of panoptic systems; spatially and architecturally planters seem to have been constructing plantations in ways that were intended to contribute to the maintenance of a hierarchical power structure with the big house functioning as the tower of power.

Vlach quotes an article published in 1851 that describes the "best way" to run a plantation. He states that “. . . one Mississippi planter listed sixteen rules, the first of which he spelled out in bold capital letters: 'THERE SHALL BE A PLACE FOR EVERYTHING AND EVERY THING SHALL BE KEPT IN ITS PLACE'”'(228). This strict façade of social order as represented most obviously by the spatial arrangement and 
architectural structure of the buildings of the plantations represented more of a desired social order than could be strictly maintained:

Within the landscapes created by slaveowners, however, absolute social power was an ideal that was asserted more often than it was achieved. Much to their chagrin, planters came to realize that their systems of architectural manipulation could be easily frustrated if one simply refused, as many slaves did, to acknowledge or take notice of it. (229)

As a result, corporal punishment was more of a representation of power than any delicately balanced system of architecture. 
A need for violence in controlling slaves' behaviors would seem to highlight owners' lack of control over the slaves on their plantations; slaves constantly resisted their designated role even in the face of perpetual torment. In representations of slave plantations and the relationships between owners and slaves though, narrators often seem to imply that the owners were tormented more than slaves. Frederick Douglass states that "the slaveholder, as well as the slave, is the victim of the slave system. A man's character greatly takes its hue and shape from the form and color of things about him" (54). He adds that "there is more truth in the saying, that slavery is a greater evil to the master than to the slave, than many, who utter it, suppose" (69). In Iola Leroy, Dr. Gresham argues that "the short-sightedness of our fathers linked the negro's destiny to ours. We are feeling the friction of the ligatures which bind us together ..." (Harper 164). And Booker T. Washington asserts that “... notwithstanding the cruel wrongs inflicted upon us, the black man got nearly as much out of slavery as the white man did. The hurtful influences of the institution were not by any means confined to the Negro" (37-8). Rather than implying that owners were actually more tormented than slaves themselves, these statements indicate that slaves were not the sole victims of the slave system, and they point to the equally destructive results of repetitive violent and manipulative strategies of control and relationships of power on beth the slave and the planter classes. Furthermore, these statements point to ways in which African-American narrators had actually mastered their owners' ideology; their comprehension of the planters' violent 
strategies of governing behaviors on the plantation had been fully realized and then fully used to retaliate against and then overcome and escape from those same violent strategies. The narrators present their ability to intellectually interpret the effects of a dehumanizing system on all classes and in turn highlight their own humanity and individuality. These statements show how particular African-American narrators were capable of rhetorically resisting their_dehumanizing and anti-intellectualizing delegated position as slave through pointedly acknowledging, interpreting, and renegotiating that position within the owners' constructed boundaries. Through these rhetorical strategies, these narrators were able to affect the sensibilities of a larger audience in recognizing the need to abolish slavery; knowing the strategy for dehumanization and control enabled the authors to deconstruct that strategy and reapply that knowledge productively in influencing a different and yet similar group of people in the North. The authors had to portray themselves as unique and yet absolutely the same as their fellow African-Americans. In addition to demonstrating the need to end slavery, the authors also had to demonstrate to their audience their own "resignation" to a distinct and separate class of people as a whole that could function among and sympathize with the entire white class of people in America. African-American narrators were fully cognizant of their readership, the majority of which was white and, while for the most part in favor of abolishing slavery, not fully comfortable with the idea of the African-Americans' equality with themselves in all aspects. Furthermore, their readership identified itself with the white population in America, a white population which included the slave owners of the South, much more closely than it identified itself with the African-American 
population. African-American narrators were forced to address a public sphere which recognized the black race as naturally different based on their skin color. Narrators therefore offered accounts of individual slave lives as representative of AfricanAmericans occupying a homogenous and distinct black sphere of society in contradistinction to the homogenous and privileged sphere of white society. Frances Smith Foster argues that "in order for the narrative to attract the largest number of readers and to focus attention upon slavery, the individual had to identify himself with the masses of slaves" (68); the narrators presented themselves as symbols of the universal slave. The image of all slaves had to be regarded with pity in order to evoke the appropriate responses, the appropriate debate and discussion within the white public sphere, that would contribute to ending the institution. Narrators produced universal representations using the language of the dominant white public while at the same time subverting and disrupting the norms of that same public sphere. While narrators may have written that they believed that owners suffered equally if not more than slaves in the slave system, their acknowledging a mutually dehumanizing effect of slavery functioned also as a rhetorical strategy in manipulating the white reader into sympathizing further with the narrators' "humane" approach to comprehending slavery as an owner.

Douglass's narrative offers one manner of assessing the effects of public opinion on the ways that representations of slave plantations were structured and on the particular issues they addressed. In describing Col. Edward Lloyd's plantation where Douglass spent much of his youth, Douglass distinguishes the plantation as 
existing in a separate sphere of its own, a sphere that has no relation to the outside American public sphere. He state that

That plantation is a little nation of its own, having its own language, its own rules, regulations and customs. The laws and institutions of the state apparently touch it nowhere. The troubles arising here, are not settled by the civil power of the state... There are no conflicting rights of property, for all the people are owned by one man; and they can themselves own no property. (45)

He significantly comments on the ineffectiveness of public opinion in protecting the slave from cruelty in this domain whose law and government existed separately from the national law: "On the contrary, [public opinion] must increase and intensify his wrongs. Public opinion seldom differs very widely from public practice. To be a restraint upon cruelty and vice, public opinion must emanate from a humane and virtuous community" (45). While stressing the ineffectiveness of public opinion on the practices at the plantations, Douglass also attempts to shape and affect change in his readership's public discourse and, inevitably, public opinion. In addition, this two-page section describing the lack of political and social restraint on plantations is followed by eight pages describing the magnificent and impressive landscape of the plantation. Douglass appears to soothe and cajole his audience with jolts and direct criticism interspersed among elaborations on the physical and natural beauty of the land itself that has ultimately been planned and constructed by slaveholders. In order to be believed and to be taken seriously, Douglass must cede some superior quality of life and living to the white man, whether he be Northern or Southern. 
Another example of how narrators used a mastery of planter ideology to affect the sensibilities of their readership appears in Frances Harper's Iola Leroy. A fictional account of slavery and Reconstruction published in 1892, Iola Leroy was Harper's effort to effect individual changes in her readership in order to effect greater social change (Andrews $\mathrm{x}$-xi); in establishing individual understanding of ex-slaves' situations, Harper hoped to establish a more communal sympathy. In keeping with that effort and working towards the understanding that social change could only occur with individual tenacity and diligence, Harper represents one owner's weakness and inability to act virtuously in the face of societal retribution. Her presentation of a white slave owner who is sympathetic to the slaves' situation represents one manner of her comprehending that her audience would inevitably make exceptions for slavery when considering the slave owners that they "knew" and believed to be benevolent and just; however, her presentation uses the sympathetic slaveholder's situation to manipulate her readership by never failing to continually indict the system of slavery itself.

In Iola Leroy, Harper literally allows the slaveholder, Leroy, a voice in denouncing slavery itself; however, Leroy encounters exactly the kind of public opinion that Douglass claims is resistant to "humane" treatment of slaves. Leroy represents a white plantation owner who expresses the desire to free his slaves, but is afraid of what will happen not only to himself but to his slaves if he were to act on his desire. He laments: "My hands are tied by law and custom. . . [by] a public opinion, whose meshes I cannot break. If the negro is the thrall of the master, we are just as much the thralls of public opinion" (Harper 61). Leroy states that he does not "battle 
against public opinion" because he "has neither the courage of a martyr, nor the faith of a saint; and so I drift along, trying to make the condition of our slaves as comfortable as I possibly can" (61). In addition, Lorraine warns Eugene not to "air" his "Northern notions" about slavery in public. She argues that "public opinion is too sensitive to tolerate any such discussions" (55). Eugene responds, "And is not that a proof that we are at fault with respect to our institutions?" (55). Harper presents an image of a "humane" and "dignified" white plantation owner who sees himself as bound into the system itself by public opinion. Harper's narrative recognizes and reassures her readership that the white public as a whole is not entirely lacking sympathy for the slaves; at the same time, Harper uses this white voice to represent an argument that might otherwise not be recognized coming from the mouth of a black slave.

As a whole, most representations of slave plantations written by AfricanAmericans contain seemingly sympathetic phrases and laments for the slave owners' position at some points; however, it is imperative to recognize that those words of sympathy were rhetorical strategies for encouraging the sympathies of a white readership towards slavery. Furthermore, those strategies represent the narrators' continuing to function within a designated social space even as they wrote from their "liberation" in the North. While physical violence may have been left on the plantation, the fact that mental coercion and manipulation continued to influence African-Americans' behaviors even outside of the plantation South contributes to the argument that the slave system functioned using at least some form of surveillance that reached far beyond the big house. 
On the plantation, owners who were able to instill a sense of their presence through their watch over slaves even in their physical absence seemed to maintain a more predictable and less apparently physically violent environment; control and discipline never functioned without continual threats to slaves' lives, but the arrangement of the landscape provided a concrete physical representation of owners' attempts to enforce and maintain their desired social and class demarcation. Foucault argues that "discipline makes possible the operation of a relational power that sustains itself by its own mechanism and which, for the spectacle of public events, substitutes the uninterrupted play of calculated gazes" (DP 177). This analysis suggests that a partial regime of surveillance contributed to furthering the interest of the slave owner who wished to maintain a position of authority and have the plantation function efficiently. The landscape was intended to create a field of vision that acted as a supplementary and strategic disciplinary technique which set up constructed gazes of control and power among all members of the plantation. For the most part, however, the gaze factored in as such a small part of the total government of the plantation that owners always resorted to physical violence and discipline in controlling the slaves.

Douglass seems to contend that slaves who dared to retaliate violently to physical abuse at times were able to achieve a kind of control over their own bodies in future disciplinary actions against them; when a slave fought back, the overseer, according to Douglass, almost always discontinued further physical punishment. Douglass describes an incident in which Nelly, a slave on Capt. Auld's plantation, was punished for "impudence." Nelly fought back against the overseer, Mr. Sevier, and even though she was finally tied and beaten until "her back was covered with 
blood," "she was not subdued, for she continued to denounce the overseer, and to call him every vile name" (63). Afterwards, Nelly was never beaten again. Douglass explains that

He is whipped oftenest, who is whipped easiest; and that slave who has the courage to stand up for himself against the overseer, although he may have many hard stripes at the first, becomes, in the end, a freeman, even though he sustain the formal relation of a slave. (63) He contends that "the old doctrine that submission is the best cure for outrage and wrong does not hold good on the slave plantation" (63). Douglass's argument that resistance to violent forms of discipline elicited a reprieve from the physical violence inflicted by overseers is evidence of yet another disciplinary technique used by owners in constructing slaves' views of their position on the plantation. Although Douglass may appear to be arguing that physical resistance brought about a less tortured existence, a reprieve, from the violence of slavery, his recounting of this "reprieve" highlights how physical manipulation functioned. Even though slaves may not have been beaten again if they resisted, they were still being mentally manipulated and violated. As yet another form of control used by owners in evoking desired behaviors from slaves, psychological coercion and manipulation functioned in accordance with physical punishment.

Blassingame argues that " "the best evidence of the good management of slaves, is the keeping up of good discipline with little or no punishment.' The use of coercion was an indication that the slave did not identify with the master's interest and refused to play the submissive role" (245). Since owners' control on their 
plantations was impossible without implementing coercion and punishment, as an additional strategy in attempting to induce submission from slaves and to appear to be managing a functioning system of government, owners arranged their plantations panoptically.

Nevertheless, the constructed landscape and arrangement of a plantation, while aesthetically representing and physically indicating the presence of the function of owners' desired order and control on the plantation, failed to condition slaves to think as their owners thought and to resign themselves to their delegated position. Less violent owners may have had slaves who appeared to comply with rules and regulations more readily and seemed to have appropriated the planter ideology, but the appearance of complicity was significantly different from the slaves' actually having complicit thoughts or even actually complying with the rules and regulations of the plantation. Behind closed doors slaves often managed to create individual aspects of their own lives in subtle and yet effectively resistant ways. In the open, out in direct confrontation with the gaze of owners, slaves were also capable of manipulating the constructed landscape in ways that produced some benefits for them and served as sites of resistance to the intended system.

The slaves in fact appropriated the masters' governmentality in many ambivalent ways; their comprehension of the desired social structure often became their impetus and resource for devising ways to retaliate against the system. Ball attests to the slaves' interpreting the relationship between themselves and masters in a way that fostered behaviors from slaves that would be considered immoral under other circumstances. Ball writes that 
I was never acquainted with a slave who believed, that he violated any rule of morality by appropriating to himself anything that belonged to his master, if it was necessary to his comfort. The master might call it theft, and brand it with the name of a crime; but the slave reasoned differently, when he took a portion of his master's goods, to satisfy his hunger, keep himself warm, or to gratify his passion for luxurious enjoyment. (390)

Slaves, in this instance, saw their master's land and belongings as land and belongings of which they were, by virtue of being a part of, privileged to confiscate at their own discretion; one cannot steal from oneself, and therefore slaves' "appropriation" of owners' "belongings" was simply slaves' taking what was rightfully theirs to begin with.

Ball describes a "mutual dependence between the master and his slave" that he argues was not taken into account by most slaves (390): “The former could not acquire any thing without the labour of the latter, and the latter would always remain in poverty, without the judgment of the former in directing labor to a definite and profitable result" (390). In his description of how slaves appropriated plantation ideology into their own system of ownership and belonging, though, Ball provides a good description of how slaves were capable of manipulating the intended "place" in which they were designated.

In the way that Ball interprets the relationship between slaves and masters, he himself demonstrates the effect that the ideology of his own masters had on his perspective of plantation management and government even in his position as an ex- 
slave. Outside of the plantation system, his perspective of slavery changed and the way that he was perceived, as an escaped slave, changed. His interpretation of his new place as an educated man within the social structure of the North highlights how privileged "viewpoints" could create relationships of understanding that positioned the ex-slave more closely within a planter ideology than it represented a constructive interpretation of slaves' logical analyses and responses to that ideology. He states that

ignorant men do not and cannot reason logically; and in tracing things from cause to effect, the slave attributes all he sees in possession of his master, to his own toil, without taking the trouble to examine, how far the skill, judgment, and economy of his master may have contributed to the accumulation of the wealth by which his residence is surrounded. $(390)$

In crediting masters with insuring slaves' organization and successful production economically, Ball distances himself from the slave population and serves as an example of how he has been indoctrinated into a form of plantation ideology from "the other side," from a privileged position of power that has given Ball a language with which to represent the slaves' comprehension of their place.

As troubling as Ball's statement is in its implications of how he sees that slaves "should" have interpreted their place, Ball highlights the effect of owners' presenting a façade of grandeur to their slaves. While pointing to his own inclination to respond to the landscape in ways that were closer to owners' desires after the fact, his statement indicates that the effect obviously acted in opposition to owners' desires 
of evoking admiration and reverence through the landscape for most of the slaves on the plantation. Instead of creating a sense of reverence and admiration through their landscape construction, masters created a sense of loathing and hate. According to Ball, rather than reinforcing the idea in slaves that their place was a necessary and desirable position from which to live and work, the landscape's beauty presented and represented everything that the master was denying them.

Douglass describes one way in which slaves attempted to appropriate a certain amount of ownership and power that transcended their limited position as slaves. $\mathrm{He}$ contends that, in many cases, slaves appropriated their masters' desires in ways that would help increase their own sense of self worth while not necessarily internalizing the desire to better the plantation as a system itself. Living on the largest and grandest plantations demanded that slaves from less prosperous plantations respect and admire the slaves with wealthier owners: "They seemed to think that the greatness of their masters was transferable to themselves" (76). He adds, though, that this attitude arose only in the presence of slaves from other plantations, and, when among the slaves of their own plantations, the slaves would complain and dissociate themselves from their masters' positions. Slaves in this instance, much like the slaves that Ball discusses, participated in an identification with the results of their toil in empowering ways, and they rejected the idea that the positive representations of their work belonged solely to their owners.

Ultimately, slaves and owners needed each other to cooperate in order for any kind of plantation government to exist. Both groups knew that they were necessary to each other in this process, but slavery itself precluded the ability for slaves to 
compromise their delegated position within the system or to participate reciprocally in any relationship that would be productive for the planter or anyone else involved. In the face of the continually failing slave system, owners appear to have acknowledged the existence of some sort of power relationship with slaves. Simply stating that slaves were not individuals with individual will did not eliminate or negate the fact that slaves in fact were individuals with individual will. Therefore, in attempting to discipline their behaviors and maintain control in larger arenas, slave owners subtly negotiated their own failure to recognize slaves' humanity by permitting slaves certain liberties within the boundaries of the plantation landscape.

Slave narratives locate instances of these liberties in their texts. The narratives describe what could be considered tolerated spaces of illegality within the plantation that allowed slaves a minimal and limited agency. Blassingame notes that government of slaves was often a difficult and complicated process, and he states that "the planters realized that since the slaves had not internalized their ideals they had to make several compromises in order to maintain the façade of absolute control" (277). This façade included "refusing to take note of every deviation from the rules": "each planter had to learn to be selectively attentive to rules infractions" (280). Here again masters were utilizing a form of discipline that historically functioned prior to Bentham's Panoptic arrangement; their discipline in this sense acted crudely and indicates that their architectural and spatial arrangements of buildings was more supplemental and complementary to violent means of control and power than it was a functioning disciplinary mechanism of a practiced panoptic system. Foucault, in his describing "tolerated illegality" under the Ancien Regime, highlights the significance 
of this tolerance in maintaining order and seems to represent a description of the kind of discipline that owners were enforcing:

The least-favored strata of the population did not have, in principle, any privileges: but they benefited, within the margins of what was imposed on them by law and custom, from a space of tolerance, gained by force or obstinacy; and this space was for them so indispensable a condition of existence that they were often ready to rise up to defend it. $(D P 82)$

While these limited spaces of contestation act hegemonically, they also prove that slaves were able to make decisions while being disciplined; while slaves' "possible fields of action" were "structured," they still retained the power to pick fields in certain instances that affected the ways that they were treated by owners.

Certain buildings originally represented spaces where these choices could be made, with the owners' conceiving of that space as not producing for slaves the ability to disrupt the plantation system outside of the four walls of that designated space. For example, slaves on some plantations and in some rare instances were allowed to meet in their own churches at times without having any white body present to watch over them. This privilege was not without its definitive limitations and boundaries set by masters. In Harriet Jacobs' Incidents in the Life of a Slave Girl, Linda Brent discusses "their little church in the woods" where the slave community in her vicinity met (67). She explains that one of the repercussions of Nat Turner's rebellion in her area was the destruction of that church and the revocation of the 
privilege of their being allowed to congregate and worship without the presence of any white man or woman:

The slaves begged the privilege of again meeting at their little church in the woods, with their burying ground around it. It was built by the colored people and they had no higher happiness than to meet there and sing hymns together, and pour out their hearts in spontaneous prayer. Their request was denied, and the church was abolished. (67) The destruction of the church was most likely a direct result of Turner's radical Christianity and belief that he was a Christ figure come to save the slave population by eliminating white people. Jacobs explains that after Turner's rebellion and after her church was destroyed, slaves were allowed to worship only in white churches and under the direct observation of masters and overseers. While religion was deemed necessary by masters (as yet-another space for creating an ideological control over slaves), the incorrect kind of worship with respect to masters' intent (as specifically represented by Turner's religious fanatacism) was threatening and therefore abolished through abolishing a representative space where that unsupervised type of discourse might function. Even the limited freedom of the space within the church became too much after masters realized that slaves could use that space to confer and retaliate. Masters, however, could not and did not eliminate every possible opportunity for slaves to meet and to imagine venues for resistance.

As a result of tolerated spaces of illegality where owners regulated and limited a minimum amount of freedom for slaves, slaves often took advantage of opportunities to overstep and act beyond the "tolerated spaces" in ways that 
represented significant resistance to the rules and an ability to maneuver skillfully around and within those rules without being detected. While many spaces are discussed, the outer boundaries of the plantation and the slaves' quarters are two of the most recurring spaces in slave narratives where slaves were permitted certain illegalities but also managed to create opportunities for their own resistance and agency against the intended definitions of those spaces within the plantation system.

Significantly, a slave's familiarity with the landscape of the plantation would seem to indicate an identification with the relationships among buildings and a recognition of the immense scope of owners' possessions; to know the territory owned by the slaveholder was to know the slaveholder's boundaries and the slaveholder himself through the land as his representative body of power. Knowledge of the landscape, however, often worked in favor of slaves; many times slaves knew the land and the boundaries of the plantation much better than the owners and overseers themselves.

Douglass utilized his extensive knowledge of the outlying areas of one plantation on which he lived in order to teach slave children, a subversive and illegal act. Douglass's ability to establish a "Sabbath school" twice "in the woods, behind the barn, and in the shade of trees," without being immediately detected illustrates how slaves could use spaces that were less familiar to their masters for resistant purposes (162). When the opportunity arose to carry on his meetings in the home of a free colored man "who lived several miles from our house" (164), Douglass and his students escaped from the plantation territory and attended lessons at that house in secret. Douglass acknowledges that each time they left the plantation, they "came 
under the liability of having forty stripes laid on their naked backs" (164), but they went nonetheless and were not caught. The fact that at times Douglass had "more than forty scholars" attending his lessons at the freeman's house highlights the significance of slaves' ability to escape from the sight of the overseers and owners; furthermore, the fact that the slaves were learning to read and therefore "endangering slave rule" and "the peace of slavery" (163) during the time that they were out of sight of the owners and overseers indicates their success in resisting their position as slaves in addition to resisting owners' psychological oppression.

Slaves often would sneak away from plantations in order to visit lovers or family members on other plantations; knowing the layout of the plantation allowed slaves to travel discretely and unnoticed. Ball explains that it was "common for the slaves to absent themselves from their habitations at night, and if the matter is not discovered by the overseer or master, nothing is ever said of it by the slaves" (393). As a result of this, it was possible for Douglass's mother to visit him while he was living as a child in the kitchen of Col. Lloyd's plantation: "Her visits to me there were few in number, brief in duration, and mostly made in the night. The pains she took, and the toil she endured, to see me, tells me that a true mother's heart was hers, and that slavery had difficulty in paralyzing it with unmotherly indifference" (39).

Although his mother's visits may seem insignificant, her being able to maneuver within the space of the plantation and so close to the big house without detection implies that she was extremely familiar with the landscape and the intricacies of the spaces which were most carefully guarded on the plantation. While slaveholders must have had some idea that slaves were not exactly where they were believed to be 
at each and every minute of the day and night, they allowed this limited movement as a result of their inability to keep a constant physical eye on every single slave. In many cases, slaves used their owners' limited control and power in order to acquire more than just a brief night away from the plantation.

Slave narratives discuss accounts of slaves running away into the surrounding woods of the plantation and remaining hidden for days, weeks, or even years. Nat Turner, in The Confessions of Nat Turner, recounts his running away from a particular overseer into the woods (46). He remained there for "thirty days" and returned on his own volition, "to the astonishment of the negroes on the plantation, who thought I had made my escape to some other part of the country, as my father had done before" (46). Turner exhibits through his action a certain amount of freedom from sight that must have existed in order for him to initially run; furthermore, the fact that he was not discovered in a thirty day period indicates that his knowledge of the landscape had to have been somewhat superior to that of those men in charge of the plantation government that were seeking him out.

Even more than a representation of a slave's ability to act on his free will or prove a consecrated invincibility, as appears to be the case with Turner, running away also presented a very successful means for controlling and manipulating owners' behaviors. In Dorothy Sterling's collection of slave women's recountings of particular incidences in their lives as slaves, Sterling writes that "women tried every way they could to keep their children from being sold" (58), and one of these ways included escaping into the lesser-known areas of the plantation itself. She includes one slave's explanation of how her mother 
often hid us all in the woods, to prevent master selling us. When we wanted water, she sought for it in any hole or puddle formed by falling trees or otherwise. ...For food, she gathered berries in the woods, got potatoes, raw corn \&c. After a time, the master would send word to her to come in, promising he would not sell us. (59)

In addition, Sterling includes accounts of slave women who managed to run away and live in caves within the woods of the plantation without discovery for years on end. One slave's sister managed to escape from slave traders into the woods near her family (61). The girl "lived in a den she made for herself" (61). Another slave's husband "fixed [a] cave up just like a house for her, put a stove in there and run the pipe out through the round into a swamp" (61). The woman lived in the cave for seven years, where she gave birth to and raised three children: "Our Marster didn't know where she was, and it was freedom before she come out of that cave for good" (61). For seven years, the slave woman managed to live within the boundaries of the plantation without being discovered. By utilizing the space of the decentralized territory of the plantation, slaves, as the designated masters of decentralized spaces, were able to gain some authority and power over owners.

While types of slave resistance varied in intensity and effect, and while the outer limits of plantations provided spaces for resistance in undeveloped areas, many forms of resistance occurred inside the central territory of the plantation, specifically within the space of the slave cabins. Closer to the big house, the slaves' quarters were spaces where owners still were forced to recognize certain limitations to their gaze. As a result, owners allowed certain behaviors to be carried out within those 
spaces with the belief that those behaviors would ultimately entail no immediate threat to the plantation system or the owners' power.

While slaves' quarters functioned mostly in favor of owners, they actually represent one area where slaves could maintain a minimum amount of control of their own individual behaviors even as they acted under the eye of the overseers and owners. At one point in Iola Leroy, Robert tells Captain Sybil about secret meetings that the slaves held (Harper 36). He explains that his "ole Miss" implicitly allowed these meetings by enforcing the respect for particular boundaries between the plantation at large and the slaves' quarters: "She never wanted the patrollers around prowling in our cabins, and poking their noses in our business" (Harper 36). Genovese argues that "within the cabin the power of the master could be shut out temporarily" (534). Even when masters attempted to control the space inside the cabin by "taking measures to get their slaves to bed early" and "[forbidding] nocturnal singing and audible recreation," slaves often "did it anyway at the risk of punishment" (534). When slaves entered their individual cabins, their lives in those cabins may have been intended to be lives of workers with no freedom and no thoughts of escaping their situation, but slaves were at times able to manipulate the space of those cabins in beneficial ways for themselves.

Ball supports this idea in his explanation for why he would rather remain in his cabin than go to the sick room when he becomes ill from working in the rice paddies; he chooses "to remain at the quarter, where I was my own master" (399). The fact that Ball had a choice of whether to stay in his cabin or go to the sick room is one example of how owners appeared to give a slave a limited amount of freedom. In 
addition, without going into detail, Ball's statement implies that there was relative control over one's own actions in his own cabin, as opposed to the imposed behavior under direct supervision in the sick ward or in the field under the overseer. By refusing to be moved to the sick ward, Ball could take control of his own recovery in a space less maintained by masters.

Furthermore, Ball describes in several places his own tactics for secreting away certain foods within the space of his cabin that would have been considered contraband and would have caused him severe punishment upon discovery by overseers or the owner. At one point in his narrative, he illegally obtains "a hundred pounds of good flitch bacon" and "stowed it away in an old salt barrel, and safely deposited it in a hole, dug for the purpose in the floor of my cabin" (391). Ball also notes that his familiarity with the landscape of the plantation aids him in obtaining extra supplies: "I had, by this time, become in some measure, acquainted with the country, and began to lay and execute plans to procure supplies of such things as were not allowed me by my master" (374). Not only is he able to trap wild animals for food and sell their skins, he also discovers areas where he can collect turtles in order to store them away for later consumption. These turtles he "carries home," and "put[s] them into a hole that I dug in the ground, four or five feet deep. ... Into this hole I poured water at pleasure, and kept my turtles until I needed them" (401). In fact, towards the end of his narrative, Ball recounts building a cabin undetected in the woods where he stored supplies in preparation for his escape from slavery (428). He describes in detail the steps he took to procure certain necessities: 
These operations, except the grinding of the corn, I carried on in a small conical cabin that I had built in the woods. . . Before the first of August I had all my preparations completed, and had matured them with so much secrecy, that no one in the country, white or black, suspected me of entertaining any extraordinary design. (428-9)

In addition to explaining how he himself manipulated slave cabin space for his own benefit, Ball recounts the story of a man who was discovered cooking a sheep that he had stolen from his master in a fire in his own cabin. The man telling Ball the story explained that "the kitchen walls [of my cabin] were open so that the light of my fire could not be concealed," and his master, upon seeing the light, "burst in" and "with a terrible oath, asked me what I was doing so late at night, with a great fire in the kitchen" (307). His master discovered the sheep, and the man was punished horribly. However, the fact that the man believed that he might possibly get away with cooking the sheep at his own fire in his own cabin indicates that he felt a certain, though small, amount of security within this space. He risked the chance of being discovered as a result of having a space in which to act against the will of his owner on his own behalf.

In a more successful example of how the slave cabin could be used against the authority of the owner, Harriet Ross, Harriet Tubman's mother, reportedly prevented her son from being traded by threatening to kill any person who dared to enter her cabin. When her master came to her door to demand her to give him her son, she replied that " 'the first man that comes into my house, I will split his head open.' That frightened them, and they would not come in. So she kept the boy until the Georgia 
man went away" (Sterling 59). While the slave cabin would normally be considered relatively penetrable and unsafe, in this instance it provided a space where Ross could protect her family and, for the moment, resist the demands of her owner successfully.

Slaves' abilities to maneuver through the landscape and their limited success in manipulating and protecting the space of their cabins represent small and yet significant areas of resistance to owners' attempts at establishing a functioning panoptic system. While these spaces of resistance were never actually owned by slaves and failed to ultimately give slaves any real power in changing their position as slave, these acts of resistance are significant in their representation of the futile nature of owners' attempts to establish any strategy for creating slavery as a legitimate form of government.

Obviously, panopticism was only one tactic used by owners in attempting to establish forms of physically nonviolent discipline on the plantation; it was not the only tactic that failed. Genovese's explanation of the failure of owners' paternalistic attempts at managing their plantations points specifically to the impossibility of any nonviolent discipline and governance functioning in the slave system:

For the slaveholders paternalism represented an attempt to overcome the fundamental contradiction in slavery: the impossibility of the slaves' ever becoming the things they were supposed to be.

Paternalism defined the involuntary labor of the slaves as a legitimate return to their masters for protection and direction. But, the masters need to see their slaves as acquiescent human beings constituted a moral victory for the slaves themselves. Paternalism's insistence upon 
mutual obligations-duties, responsibilities, and ultimately even rights-implicitly recognized the slaves' humanity. (5)

While denying slaves their humanity and individuality, masters were ultimately forcing slaves to assume individual responsibility for their actions and to accept individual rewards for their complicity. Slaves were required to recognize themselves as chattel with no rights and no free will, but they were also forced to accept a role that compelled them to make decisions and to choose to follow orders in situations that could only be negotiated by thinking and feeling individual human beings. While owners may have wanted to efface slaves' humanity, their own strategies in attempting to maintain control and order on the plantation emphasize and continually reveal the impossibility of this effacement.

Nikolas Rose and Peter Miller specifically recognize the difficulties of any type of government succeeding, and, according to their argument, it would be virtually impossible for a governmental system to function on a slaveholding plantation under any circumstances. Rose and Miller argue that entities and agents within governmental networks are not faithful relays, mere creatures of a controller situated in some central hub. They utilise and deploy whatever resources they have for their own purposes, and the extent to which they carry out the will of another is always conditional on the particular balance of force, energy and meaning at any time and at any point. Each actor, each locale, is the point of intersection between forces, and hence a point of potential resistance to any one way of thinking and acting, or a point of 
organization and promulgation of a different or oppositional

programme. (190)

Individual will can neither be eradicated nor predicated, and reactions to situations will inevitably vary and consequently disrupt systems that fail to recognize and adjust to the unpredictable or undesirable. While slavery as an institution denied individual will, it paradoxically insisted on individual restraint and composure, on awareness of individual actions and repercussions, with respect to strategies of control that defined the slave's role. Rose and Miller state that "things, persons, or events always appear to escape those bodies of knowledge that inform governmental programmes, refusing to respond according to the programmatic logic that seeks to govern them" (190). Owners attempted to govern plantations as self-sustaining worlds of their own, where nothing from the outside could enter and nothing from the inside could escape (including thoughts and actions). They strove for stasis and permanence that would eliminate conflict and result with their power and place being reinforced no matter what situation arose. The slave narratives contribute to determining to some extent just how miserably the plantation owners failed at this project. While using physical nonviolence as a supplement to corporal punishment and force in conditioning the consciousness of slaves towards a planter mentality and codependence, it was still a type of governance based on an unsuitable and, obviously, inhumane institution. Rose and Miller argue that "government is a congenitally failing operation: the sublime image of a perfect regulatory machine is internal to the mind of the programmers" (190). While what the slaveholders had in mind might have seemed to their eyes to be the best approach to attempting to 
achieve a functioning government of the slave plantation, one must keep in mind that the view from the big house was always limited. 


\section{Bibliography}

Althusser, Louis. "Ideology and Ideological State Apparatuses (Notes towards an Investigation." 127-86.

Balibar, Etienne. "Class Racism." Race, Nation, Class: Ambiguous Identities. Eds. Etienne Balibar and Immanuel Wallerstein. Trans. Chris Turner. London: Verson, 1988. 204-16.

Blassingame, John W. The Slave Community: Plantation Life in the Antebellum South. New York: Oxford UP, 1979.

Bonner, James C. "Plantation Architecture of the Lower South on the Eve of the Civil War." Journal of Southern History 11(1945):370-88.

Brown, Gilian. Domestic Individualism. Berkeley: University of California Press, 1990. 13-60.

Brown, William Wells. Clotel: or, the President's Daughter: A Narrative of Slave Life in the United States (1853). Three Classic African-American Novels.

Ed. William L. Andrews. New York: Mentor, 1990. 71-284.

Burchard, John and Albert Bush-Brown. The Architecture of America: A Social and Cultural History. Boston: Little, Brown and Company, 1961.

Chambers, Simone. Reasonable Democracy: Jurgen Habermas and the Politics of Discourse. Itaca: Cornell UP, 1996.

Conzen, Michael P. The Making of the American Landscape. Boston: Unwin Hyman, 1990.

Douglass, Frederick. My Bondage and My Freedom (1855). Ed. William L. Andrews. Chicago: University of Illinois Press, 1987.

Foster, Frances Smith. Witnessing Slavery: The Development of Ante-Bellum Slave Narratives. $2^{\text {nd }}$ ed. Madison: University of Wisconsin_Press, 1979.

Foucault, Michel. Discipline and Punish: The Birth of the Prison. Trans. Alan Sheridan. New York: Vintage, 1977.

Power/Knowledge: Selected Interviews and Other Writings, 1972-1977. Ed. Colin Gordon. New York: Pantheon Books, 1972. 63-77, 146-65.

"Afterword: The Subject and Power." Michel Foucault: Beyond Structuralism and Hermeneutics. Eds. Hubert L. Dreyfus and Paul Rabinow. Chicago: 
University of Chicago Press, 1982. 208-26.

Fraser, Nancy. "Rethinking the Public Sphere: A Contribution to the Critique of Actually Existing Democracy." Habermas and the Public Sphere. Ed. Craig Calhoun. Cambridge, MIT Press, 1992. 108-42.

Genovese, Eugene D. Roll, Jordan, Roll: The World the Slaves Made. New York: Vintage Books, 1972.

Habermas, Jurgen. The Structural Transformation of the Public Sphere: An Inquiry into a Category of Bourgeois Society. Trans. Thomas Burger. Cambidge: MIT Press, 1998.

Harper, Frances. Iola Leroy (1892). The African-American Novel in the Age of Reason: Three Classics. Ed. William L. Andrews. New York: Mentor, 1992. 1-212.

Hudgins, Carter L. and Elizabeth Collins Cromley, eds. Gender, Class, and Shelter: Perspectives in Vernacular Architecture, $V$. Knoxville, University of Tennessee Press, 1995.

Jacobs, Harriet A. Incidents in the Life of a Slave Girl (1861). Ed. Jean Fagan Yellin. Cambridge: Harvard UP, 1987.

Levine, Robert S. Martin Delany, Frederick Douglass, and the Politics of Representative Identity. Chapel Hill: University of North Carolina Press, 1997.

Owens, Leslie Howard. This Species of Property: Slave Life and Culture in the Old South. Oxford: Oxford UP, 1976. 136-63.

Rose, Nikolas and Peter Miller. "Political Power Beyond the State: Probematics of Government." 173-205.

Ryden, Kent C. Mapping the Invisible Landscape: Folklore, Writing, and the Sense of Place. Iowa City: University of Iowa Press, 1993.

Singleton, Theresa A. "Introduction." The Archaeology of Slavery and Plantation Life. Ed. Theresa A. Singleton. Orlando: Academic Press, Inc., 1985. 1-12.

Smith, J. Frazer. Plantation Houses and Mansions of the Old South. New York: Dover Publications, Inc., 1993.

Stampp, Kenneth M. The Peculiar Institution: Slavery in the Ante-Bellum South. New York: Alfred A. Knopf, 1969. 279-82, 292-5, 322-49. 
Stepto, Robert B. From Behind the Veil: A Study of Afro-American Narrative. Urbana: University of Illinois Press, 1979.

Upton, Dell and John Michael Vlach, eds. Common Places: Readings in American Vernacular Architecture. Athens: University of Georgia Press, 1986.

Vlach, John Michael. Back of the Big House: The Architecture of Plantation Slavery. Chapel Hill: University of North Carolina Press, 1993.

" 'Without Recourse to Owners': The Architecture of Urban Slavery in the Antebellum South." Shaping Communities: Perspectives in Vernacular Architecture, VI. Eds. Carter L. Hudgins and Elizabeth Collins Cromley. Knoxville: University of Tennessee Press, 1997. 150-60.

Warner, Michael. "The Mass Public and the Mass Subject." The Phantom Public Sphere. Ed. Bruce Robbins. Minneapolis: University of Minnesota Press, 1993. 234-56.

Wiencek, Henry. Great American Homes: Plantations of the Old South. Birmingham: Oxmoor House, 1988.

Williams, Richard E. Hierarchical Structures and Social Value: The Creation of Black And Irish Identities in the United States. Cambridge: Cambridge UP, 1990. 